\title{
Abstractacta Iranica
}

Revue bibliographique pour le domaine irano-aryen

Volume 23 | 2002

Comptes rendus des publications de 2000

« Ecological constraints and the organization of pasture rights among mobile Islamic herders ", in : Daniel Balland, éd., Hommes et terres d'islam. Mélanges offerts à Xavier de Planhol. Téhéran, IFRI (Bibliothèque Iranienne 53), 2000, t. I, pp. 205-226.

Jean-Pierre Digard

\section{OpenEdition}

\section{Journals}

Édition électronique

URL : http://journals.openedition.org/abstractairanica/35692

DOI : 10.4000/abstractairanica.35692

ISSN : 1961-960X

Éditeur :

CNRS (UMR 7528 Mondes iraniens et indiens), Éditions de l'IFRI

Édition imprimée

Date de publication : 15 mai 2002

ISSN : 0240-8910

Référence électronique

Jean-Pierre Digard, « «Ecological constraints and the organization of pasture rights among mobile Islamic herders », in : Daniel Balland, éd., Hommes et terres d'islam. Mélanges offerts à Xavier de Planhol. Téhéran, IFRI (Bibliothèque Iranienne 53), 2000, t. I, pp. 205-226. », Abstracta Iranica [En ligne], Volume 23 | 2002, document 366, mis en ligne le 08 février 2010, consulté le 25 septembre 2020. URL : http:// journals.openedition.org/abstractairanica/35692; DOI : https://doi.org/10.4000/abstractairanica. 35692

Ce document a été généré automatiquement le 25 septembre 2020

Tous droits réservés 
« Ecological constraints and the organization of pasture rights among mobile Islamic herders ", in : Daniel Balland, éd., Hommes et terres d'islam. Mélanges offerts à Xavier de Planhol. Téhéran, IFRI (Bibliothèque Iranienne 53), 2000, t. I, pp. 205-226.

Jean-Pierre Digard

Sur la base d'un vaste dépouillement bibliographique (quelque cent titres) concernant une quarantaine de groupes de pasteurs, du Maroc à l'Asie centrale 覧 dont un quart de tribus d'Afghanistan et d'Iran 医, l'A. tente de mettre en rapport les types de droits sur les pâturages (collectifs, individuels, etc.), d'une part, et les contraintes environnementales (précipitations, végétation, etc.), d'autre part. Deux ensembles sont ainsi dégagés, sans que l'on saisisse toutes les causes et toutes les implications de cette vaste entreprise de comparaison, qui reste malheureusement, de ce fait, cantonnée à un niveau très empirique.

INDEX

Thèmes : 16.1. Iran 
AUTEURS

JEAN-PIERRE DIGARD

CNRS - Paris 